CONVERSANDO

COM A MÍDIA

\section{HELENA MAFFEI CRUZ
Instituto Noos \\ HELENA MAFFEI CRUZ
Instituto Noos}

\title{
DESOBEDIENCE - A PERSPECTIVA RELACIONAL DA LIBERDADE
}

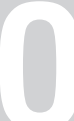

filme Desobedience, dirigido por Sebastián Lelio, com roteiro adaptado do livro O Poder, de Naomi Alderman, com Rachel Weisz e Rachel McAdams nos papéis principais, respectivamente, de Ronit e Esti, apresenta-nos com rara delicadeza a comovente história de duas mulheres que se amam, o dilema entre seus desejos e, na minha leitura, a escolha sob a perspectiva relacional da liberdade.

A primeira cena apresenta Rav, um rabino, pregando para um conjunto de religiosos na sinagoga de uma pequena comunidade judaica ortodoxa, na Inglaterra. Tratando do tema de nossos desejos que se opõem às leis de Deus, descreve 3 criações divinas: os anjos, os animais e, por último, os seres humanos. Os primeiros são executores da vontade de Deus, os segundos agem por puro instinto e os últimos são animais especiais, com o privilégio e o fardo da escolha. Vivemos o combate entre o que nos aproxima da animalidade e o que nos aproxima dos anjos. Trata-se, portanto, de uma escolha pessoal entre se aproximar de Deus ou do demônio. Não há referência a quais relações humanas estão implicadas nesses desejos, sendo privilegiadas ou maltratadas. É cada um diante do bem e do mal. Antes de finalizar seu discurso, o rabino, respeitadíssimo como um homem santo, cai morto, deixando a comunidade desolada.

Somos então apresentados a Ronit, sua filha que havia abandonado a comunidade religiosa, mudando para Nova York, onde é fotógrafa de sucesso - significativamente a cidade símbolo da realização de desejos impuros, liberdade sexual, busca de sucesso e dinheiro: o reino da desobediência aos imperativos do judaísmo ortodoxo.

Voltando para a comunidade, é recebida, com surpresa, por David, seu primo e o discípulo mais destacado de seu pai, e por uma moça, Esti, o que a espanta muito. O que estaria fazendo Esti (que ainda não sabemos quem é) lá? Minutos após esse encontro, Ronit fica sabendo que Esti se casou com David. Percebemos que há algum constrangimento dos três diante dessa revelação.

O filme prossegue com os preparativos para o enterro e a cerimônia na sinagoga da nomeação do sucessor do amado rabino Rav, o estranhamento e também repúdio da comunidade em relação à volta de Ronit, que cobra de David o fato de não tê-la avisado da morte do pai. Ficamos sabendo que Esti e Ronit tinham sido namoradas e Ronit havia se afastado da comunidade e da religião mudando para Nova York. Apontaria seu movimento para uma desistência da realização do desejo pessoal e um cuidado com seu pai, uma vez que ele passaria uma vergonha tão grande diante da comunidade que talvez não tivesse condição de continuar como o rabino mor?

Em uma vinheta sobre o filme lemos o seguinte: "Ronit precisa voltar para sua cidade natal após a morte de seu pai, um rabino. Uma vez de volta ela recorda a paixão proibida pela melhor amiga de infância, agora casada com seu primo, e as duas exploram os limites da fé e sexualidade". Como afirmei na minha leitura, os limites das consequências da satisfação de desejo. 
Os pais de David, tios de Ronit, recebem-na com manifestações muito diferentes; às manifestações de alegria e carinho com forte e longo abraço da tia, segue-se um seco e curto cumprimento do tio. Admiração da tia pela coragem da sobrinha de se manter só em um mundo tão diferente? Em se livrar das fortes imposições religiosas?

$\mathrm{Na}$ secura do tio a clara desaprovação pelo abandono da rígida moral da comunidade? Essas perguntas e outras tantas sobre olhares maldosos de outras mulheres, e a aproximação cada vez mais evidente de Esti são provocadas no/a espectador/a pela contenção verbal presente na maior parte do filme, sustentada por forte comunicação não verbal de ótimos atores.

O desenrolar da relação Esti - Ronit é uma sequência de torturantes entregas e recuos, até um momento em que Ronit toma a decisão de fugirem por algumas horas da ansiedade e medo, saindo da comunidade e indo para um motel em outro lugar.

Depois da entrega, a volta. Esti entra em casa, onde o marido desesperado esperava-a adivinhando o motivo de sua ausência. Estão prestes a ir para a cerimônia de nomeação de David para o cargo do falecido Rav.

$\mathrm{O}$ assustado marido recebe uma Esti decidida a terminar a agonia, pedindo aos gritos por sua liberdade, anunciando que está grávida e quer que seu filho nasça livre. De quê? Para quê? Vamos ver na sinagoga um David que, atônito e balbuciante, anuncia não poder aceitar a nomeação, grita, dirigindo-se à mulher que assiste sentada ao lado de Ronit à cerimônia - "Você está livre. Eu te dou a liberdade" e abandona a sinagoga.

Esti sai correndo atrás dele e alcança-o algumas quadras depois, puxando-o para um longo abraço. Atrás de Esti vem Ronit correndo. David enxerga-a e estende um braço para ela. A tela palpita com a emoção dos três. Sem nenhuma palavra, Ronit se afasta.

$\mathrm{Na}$ cena seguinte Ronit estará no aeroporto. Sobre o intenso amor e desejo das duas mulheres cuja realização implicaria a destruição da vida de David, prevaleceu uma escolha que Maturana (1990) consideraria livre.

Na perspectiva individualista e hedonista de nossa sociedade, liberdade aparece como o grande valor, sem especificações como livre de que, ou livre para que. O que nos levaria, no limite, à situação de opressão de todos pela liberdade total de um.

Maturana define, como condição da convivência social, a responsabilidade pelas consequências de nossas escolhas e a liberdade como o escolher se queremos ou não essas consequências.

Em uma comunidade regida por leis rígidas e, principalmente, inquestionáveis pela origem de um poder superior a todos os seres humanos, as consequências da desobediência a essas leis são a perdição da alma, uma exclusão daquele mundo.

A saída de Ronit da comunidade teve para a maioria da comunidade esse significado. Entretanto, o filme deixa entrever nos gestos de algumas mulheres uma admiração. Quando Esti implora ao marido rabino que ele lhe dê a liberdade, demonstra a impossibilidade de se responsabilizar pelas consequências de seus atos.

Embora antevendo as consequências desastrosas para sua vida, David aceita o pedido da mulher, para permitir que ela viva seu desejo e seu amor. Passa por cima dos preceitos sagrados, e sua dor e desespero despertam a verdadeira liberdade de Esti - ela percebe que não quer as consequências de seu ato e corre ao seu encontro, seguida por Ronit. 
O abraço silencioso dos três fala mais que quaisquer palavras: a ética do cuidado torna mais possíveis as relações do que as imposições vindas de autoridade inquestionável.

\section{REFERÊNCIAS}

MATURANA, H. (1990). Emociones y lenguaje en educación y politica. Santiago, CHI: Editorial Universitária.

\section{HELENA MAFFEI CRUZ}

Psicóloga, mestre em Psicologia Clínica

Terapeuta de casais e famílias

Diretora do Instituto Noos, São Paulo, SP, Brasil

E-mail: helenamcruz@uol.com.br 